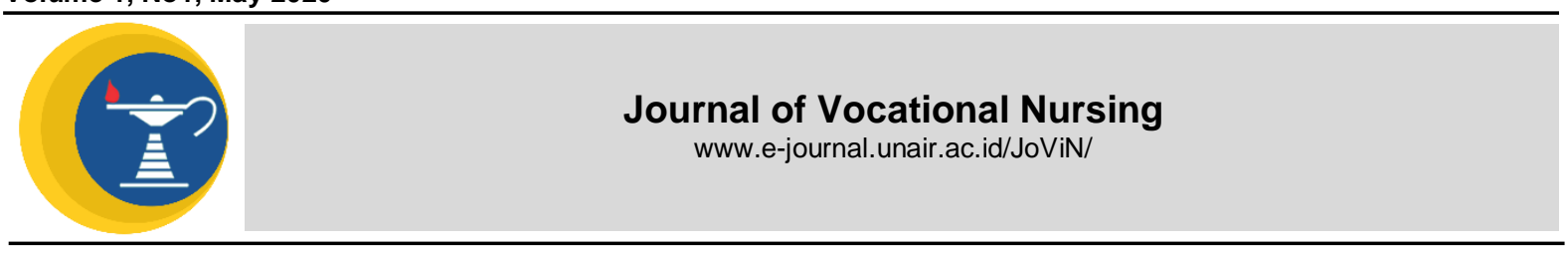

\title{
CORRELATION NURSING WORKLOAD WITH THERAPEUTIC COMMUNICATION IMPLEMENTATION
}

Research Report

\author{
Arlina Dhian Sulistyowati ${ }^{1}$, Esri Rusminingsih ${ }^{2}$ and Wendhi Prakosa ${ }^{3}$ \\ 1,2,3 Stikes Muhammadiyah Klaten
}

\section{ABSTRACT}

Introduction: Therapeutic communication is communication between nurses and patient. Some cases and action done by nurses make nurses only focus on the action carried out without regard to therapeutic communication. This study aims to determine the correlation of nurses' workload with therapeutic communication in RSU Islam Klaten

Methods: The research design was correlation with cross sectional approach. The population in this study was inpatient room nurses.

Questionnaire was used as the instrument to collect the data from the total 80 respondents which were taken as sample using the purposive sampling technique. The data was analyzed using Kendall tau.

Results: Based on the research show that most respondents stated that work as a nurse did not become a workload of $66,3 \%$ and able to implement communication well at $63,8 \%$. There was correlation between nursing workload with therapeutic communication with $p$ value $=0,000$.

Consulsion: Based on the results analysis, there was a correlation between nursing workload with therapeutic communication implementation. The task rolling should be applied to avoid the workload and to conduct development of therapeutic communication training.

\section{ARTICLE INFO}

Recived 2 January 2020

Accepted 14 May 2020

Online 29 May 2020

*Correspondence:

Arlina Dhian Sulistyowati

*Email:

arlinadhian@gmail.com

Keywords:

Nurses, Nursing workload,

Therapeutic communication

\section{INTRODUCTION}

The role of nurses in hospitals is very important. The role of nurses is all authority possessed by nurses to carry out their duties and functions according to their competence (Ghaffar, L, 2006). The role of the nurses is a way to express the nurses activities in practice where they have completed their formal education.

Each role has three elements. The first element is an ideal role, referring to rights and responsibilities related to roles that are socially recommended or agreed upon. Second is the perceived role, the role that refers to how accepting the role (the person who accepts the role) believes he must behave in that role. Third is the role that is performed, the role that refers to what the recipient of the role actually does (Blais et al., 2006).

The workload of nurses is also greatly influenced by their work time. If the work time that must be borne by nurses exceeds their capacity, such as the amount of overtime, it will adversely affect the productivity of the nurse (Syaer, 2010).

The workload standard of health workers based on national standards explains that the number of hours a nurse works in one week is 40 hours. If the effective working day is 5 days per week, then in one day is 8 hours or 7 hours per day (Ministry of Health Republic of Indonesia, 2010. Unbalanced workload will affect the performance and service of nursing so that nursing services may not optimal and nurses will ignore their duties. A certain amount of workload can lead to innovative ideas and constructive output. The workload will not only have a negative impact, but can also have a positive impact, especially for the organization and employee satisfaction (Chie and Zuraida, 2013).

Nurses with heavy workloads will feel pressured to carry out work deemed out of their responsibilities. Nurses who feel pressured by their workload will not be able to carry out communication freely and will only carry out work that is considered their responsibility 
(Aisyana and Rahayu, 2017). Implementation of better therapeutic communication will make patients and families to feel more satisfied (Adientya and Handayani, 2012).

Therapeutic communication is communication carried out to foster relationships between nurses and patients. Therapeutic communication requires free time, while nurses with heavy workloads will feel the implementation of therapeutic communication will increase the workload. Factors that affect workload are work attitude, skill level, relationship between workforce and leaders, performance or productivity management, workforce efficiency such as workforce planning and creativity at work and on the right track at work (Sedarmayanti, 2013).

Nurses immediately take action without first doing therapeutic communication. Based on the description above, researchers are interested in researching about the "Relationship between Nurses' Workload and Therapeutic Communication in RSU Islam Klaten."

\section{MATERIALS AND METHODS}

This research is included in quantitative research. The research design used is a correlation research design with cross sectional approach.

The population in the study were 100 nurses of inpatient room in RSU Islam Klaten. Sampling of this study was conducted by means of non-probability sampling using purposive sampling technique. Inclusion Criteria: Nurses on duty, Inpatient room nurses who have worked for more than 3 years (permanent employees), Nurses who have received mandatory of sharia socialization.

Exclusion Criteria: Nurses on study permit/study assignment, Nurse on leave. In this study the number of samples used was 80 nurses.

This research was conducted in June 2019 until February 2020. The independent variable in this study is nurse workload while the dependent variable in this study is therapeutic communication. The bivariate analysis in this study was adjusted to the type of data to be analyzed, using ordinal-ordinal categorical data so that it was analyzed using Kendal tau.

\section{RESULTS}

Table 1 Frequency Distribution of Respondents Characteristics at RSU Islam Klaten.

\begin{tabular}{ccccc}
\hline & $\mathbf{F}$ & $\%$ & Mean & SD \\
\hline Age & 80 & 100 & 27,02 & $-/+4,, 471$ \\
\hline Length of & 80 & 100 & 3,06 & $-/+2,45$ \\
\hline Gurse's Work & & & & \\
\hline Male & 65 & 81,3 & \\
Female & 18 & 18,7 & \\
\hline Education & & & \\
\hline DIII Nursing & 75 & 93,8 & \\
Ners & 5 & 6,3 & \\
\hline Marital Status & & & \\
\hline Married & 37 & 46,3 & \\
\hline Single & 43 & 53,8 &
\end{tabular}

Table 2 Correlation of Workloads with Therapeutic Communication in RSU Islam Klaten

\begin{tabular}{|c|c|c|c|c|c|c|c|c|c|c|}
\hline \multirow{3}{*}{ Workloads } & \multicolumn{6}{|c|}{ Education } & \multirow{2}{*}{\multicolumn{2}{|c|}{ Total }} & \multirow{3}{*}{ tau } & \multirow{3}{*}{ p-value } \\
\hline & \multicolumn{2}{|c|}{ Good } & \multicolumn{2}{|c|}{ Enough } & \multicolumn{2}{|c|}{ Less } & & & & \\
\hline & $f$ & $\%$ & $f$ & $\%$ & $f$ & $\%$ & $f$ & $\%$ & & \\
\hline None & 51 & 63,8 & 2 & 2,5 & 0 & 0 & 53 & 66,3 & \multirow{4}{*}{0,735} & \multirow{4}{*}{0,000} \\
\hline Low Workload & 1 & 1,3 & 12 & 15 & 0 & 0 & 13 & 16,3 & & \\
\hline $\begin{array}{c}\text { Optimal } \\
\text { Workload }\end{array}$ & 4 & 5 & 4 & 5 & 3 & 3,8 & 11 & 13,8 & & \\
\hline High Workload & 0 & 0 & 3 & 3,8 & 0 & 0 & 3 & 3,8 & & \\
\hline
\end{tabular}


Jumlah

$\begin{array}{lllll}56 & 70 & 21 & 26,3 & 3\end{array}$

$3,8 \quad 80$

\section{DISCUSSION}

Based on the research show that most respondents have physical abilities as well workers psychologically appropriate and balanced in every workload received someone. This means that the workload that a person receives must be appropriate and balanced against the physical and psychological abilities of workers who receive the workload. Physical workload can be in the form of heavy work lifting, encouraging, and caring. Ilyas (2014) says the high workload of nurses can cause fatigue, fatigue. Furthermore mentioned the tiredness, fatigue of nurses occurs when nurses work more than $80 \%$ of their work time. With words another productive nurse time is approximately $80 \%$, if more then the workload nurses are said to be tall or inappropriate and need to be considered for increase the number of nurses in the treatment room.se factors are good and vice versa if these factors will not have a negative impact on elderly knowledge.

Based on statistical tests show the value of $p$ value $=0,000$. This means that there is a correlation of workload with therapeutic communication at RSU Islam Klaten. Hospital authorities must ensure that the nursing workload is reduced to facilitate effective therapeutic communication. The heavy workload was also accompanied by a lack of nurses in the inpatient installation. To minimize the workload, it can be done by balancing the number of nurses based on calculations on the workload experienced by nurses. According to the Kemenkes, a lack of nurses can cause excessive workload. Important workloads are known as the basis for knowing the work capacity of nurses so there is a balance between nurses with workloads. The work performance of a very nurse fundamental is its ability to provide maximum service to patient at the hospital. Nurse workload will greatly affect the handling of patients. Effects of workload on various outcomes, such as health, safety, and quality of work life of nurses, and care safety (Carayon and Alvarado, 2007).

High workload can be increase the occurrence of poor communication between nurses and patients, failure of collaboration between nurses and doctors, nurses and discharge nurse job dissatisfaction and decrease in nurse work performance (Carayon and Gurses, 2005). Wiyana, (2008) stated that one of the indicators of nursing service quality is patient satisfaction and nurses' attitudes to guarantee whether the care services qualified. Nursing services based on affective attitudes can encourage health and can improve the quality of health services.

The patient's negative attitude towards nurses, doing a lot of work and fatigue, lacking enough time, too much work during shifts are also considered as obstacles to communication therapy. The majority of people in the environment around the RSU Islam Klaten are Muslim and want the health services to be in accordance with the principles of the Islamic Religion norms. One of them is therapeutic communication. This is possible to provide tranquility for both patients and nurses. In this study, it can be seen that the therapeutic communication process at which stage is often forgotten to be done by nurses. From the data collection there are 4 items that are often missed. The first, nurses do not do a time contract when going to take action; second, nurses do not explain the procedure of action; the third, nurses do not do a time contract at the next meeting; and the fourth, nurses do not say goodbye and say greetings when completed action. The four items above are often overlooked because nurses are in a hurry when taking action or communication to the patient and cause it is forgetten to be done. This is a problem that can be considered serious, especially at the point where nurses don't say goodbye and don't say hello.

Islamic hospitals will certainly be inappropriate if that happens, because one of the characteristics of Sharia Hospital is saying greetings to patients before and after interacting with patients. Carrying out therapeutic communication to patients is strongly influenced by the workload. A low workload make it possible to carry out a therapeutic communication process which contains religious values that encourage patients not to forget about their Creator and it can be implemented by inviting patients to read Basmallah when going to take action and reading Alhamdulillah when finished taking action (Mukisi, 2017). Effective communication between patients and nurses is cardinal to health care. In addition to nurses' and patients'perceived barriers, the study revealed the health environment-related barriers. Health environment-related barriers also include excessive workload, unconducive environment, and environmental changes (Arkorful et al., 2020).

\section{CONCLUSION}

Based on the results and discussion, it can be concluded that therapeutic 
communication in RSU Islam Klaten is overall good. There is a correlation of workload with therapeutic communication in RSU Islam Klaten. Based on the results and discussion, it can be concluded that therapeutic communication in RSU Islam Klaten is overall good. There is a correlation of workload with therapeutic communication in RSU Islam Klaten.

\section{REFERENCES}

Adientya, G. and Handayani, F. (2012) 'Stress Pada Kejadian Stroke', Jurnal Nursing Studies, 1(1), pp. 183-188. Available at:http://ejournals1.undip.ac.id/index.p hp/jnursing.

Aisyana, M. and Rahayu, I. (2017) 'Hubungan beban kerja dengan pelaksanaan komunikasi terapeutik perawat kepada pasien di RS Aisyiyah Bojonegoro', Journal Hospital Science, 1(1). Available at: https://ejournal.stikesmuhbojonegoro.ac.id/ind ex.php/JHS/article/view/55.

Arkorful, V. A. et al. (2020) 'A Cross-Sectional Qualitative Study of Barriers to Effective Therapeutic Communication among Nurses and Patients', International Journal of Public Administration.doi:https://doi.org/10.10 80/01900692.2020.1729797.

Blais, K. . et al. (2006) Praktik Keperawatan Profesional Konsep \& Perspektif. Edited by 4. Jakarta: EGC.
Carayon, P. and Alvarado, C. (2007) 'Workload and Patient Safety Among Critical Care Nurses', ScienceDirect, 19(2), pp. 121129.

doi: https://doi.org/10.1016/j.ccell.2007.02. 001.

Carayon, P. and Gurses, A. . (2005) Nursing Workload and Patient Safety -A Human Factors Engineering Perspective. Chapter 30.

Chie, H. H. and Zuraida, R. (2013) 'Skala Pengukuran Shift Kerja, Beban Kerja, dan Persepsi Kesehatan Sebagai Stressor dengan Fasilitas Manajemen untuk Penanggulangannya', Inasea, 14(1), pp. 15-21.

Ghaffar, L, O. (2006) Pengantar keperawatan profesional. Jakarta: EGC.

llyas, Y. (2014) Perencanaan Sumber DayaManusia Rumah Sakit. Teori Metoda dan Formula. Jakarta: Pusat Kajian Ekonomi Kesehatan FKM UI.

Mukisi (2017) Pedoman Standar Pelayanan Minimal RS Syariah dan Indikator Mutu Wajib Syariah. Jakarta.

Sedarmayanti (2013) Manajemen Sumber Daya Manusia. Bandung: Grafika.

Wiyana (2008) 'Faktor Yang Berpengaruh Terhadap Kinerja Perawat di Rumah Sakit Tingkat III 16.06.01 Ambon', Jurnal Manajemen Administrasi Rumah Sakit. Universitas Maluku.

Wahit Iqbal Mubarok, (2005), Pengantar Keperawatan Komunitas 1, Jakarta: Sagung Seto.

Wasis, (2008), Pedoman Riset Praktis, Jakarta: EGC. 